\title{
Saudi English Teachers' Use of Technology in Secondary Classrooms: Perceptions, Barriers, and Suggestions for Improvement
}

\author{
Deya'a Ageel Mutlaq Alswilem* \\ Department of Curriculum and Instruction, Faculty of Education, King Saud University, Saudi Arabia
}

Corresponding Author: Deya'a Ageel Mutlaq Alswilem , E-mail: hosamh94@yahoo.com

\section{ARTICLE INFO}

Article history

Received: September 15, 2019

Accepted: November 17, 2019

Published: December 31, 2019

Volume: 10 Issue: 6

Advance access: December, 2019

Conflicts of interest: None

Funding: None

\begin{abstract}
This study sought to quantify the perceptions of Saudi English teachers towards the use of technology in secondary classrooms. To achieve this goal, seventy-six English teachers in AlJouf district of the Kingdom of Saudi Arabia responded to a questionnaire, showing that the teachers held positive attitudes toward the use of technology in the classroom. However, the participants reported several critical barriers to widespread use. These included a) the lack of teacher training, b) the lack of infrastructure (labs and classrooms), and c) the lack of technology resources (computers). The survey results suggested the need for an explicit vision and strategy for technology use. Further, the teachers suggested that the creation of a standardized physical infrastructure in conjunction with financial incentives could help to improve adoption.
\end{abstract}

Key words:

Technology,

ICT,

Barriers,

Secondary School

\section{INTRODUCTION}

The widespread use of technology since the emergence of low-cost computing has had a critical influence on many aspects of society, including education, one of the most vital aspects of life. Fleming (2013) suggested that "Teaching in the internet age means we must teach tomorrow's skills today." In this regard, technology displays an exciting potential to expand and enhance the learning process and overcome obstacles that may stand in the way of providing high-quality education at scale.

Seels and Richey (1994, p.9, as cited in Earle, 2002) defined instructional technology as "the theory and practice of design, development, utilization, management and evaluation processes and resources for learning." Okojie, Olinzock, and Okojie-Boulder (2006) considered technology integration a process of using existing tools, equipment, materials, and electronic media for the purpose of enhancing learning, asserting that technology integration is not merely the use of various software tools in teaching and argued that a broad viewpoint should include theories for integration, strategies on how to select technology, and skills to demonstrate, use, evaluate, and customize the use of technology to help learning. In a comparable way, Earle (2002) supported this assumption. He pointed out that the aim of using technology is to focus on curriculum and learning. He supported a definition of integration based on how and why, and not by the amount or type of technology used in practice.

Considering the vital role of education, it became imperative for researchers to identify the perceptions, barriers, and suggestions in the minds of teachers regarding the adoption of technology in their classrooms. Knowing these barriers is an essential first step in the improvement of educational quality for schools around the world. The research discussed below contributes to this trend by examining the use of technology by Saudi English teachers at the secondary level in the Al-Jouf district.

The relevance of this work, at its base, involves the need to prepare students to be bilingual within Saudi Arabia. Having a strong command of the native language, along with the ability to read, speak, and write English has become essential with the rise of global trade, especially in the areas of science and engineering.

\section{The Problem Statement}

Since the Internet has developed into a universal tool to find information, teachers are no longer the main source of knowledge for students. As a result, education has taken on a more learner-centered orientation rather than teacher-centered. AlAbaulkareem (as cited in Oyaid, 2009) contended 
that the role of teachers changed from that of a lecturer and a knowledge transmitter to an expert who directs students in the quest for learning.

For many years, researchers have been aware of the positive impact of technology integration in education, recognizing that it is a complicated process. Barriers that hinder information and communication technology (ICT) usage differ based on context, environment, and location (AlSulaimani, 2010; Alshumaimeri, 2019)). Unfortunately, many secondary school teachers have lacked success in integrating technology into their teaching (Aytekin, AbdulAziz, Barakat, \& Abdelrahman, 2012; Hakami, Hussin \& Dahlan, 2013 \& Alharbi, 2013).

This research examined secondary English teachers' perceptions concerning technology integration in the Al-Jouf district of Saudi Arabia. In addition, the study identified some of the barriers that prevent teachers from using educational technology. Last, this research explored teachers' suggestions to overcome the barriers.

\section{Limitations of the Study}

Like any other research, the methodology had limitations. The approach used the survey method to obtain the results, at the exclusion of other methods such as observation, interviews, or focus groups with administrators, teachers, students, or parents. Moreover, the survey concentrated only on secondary school teachers.

\section{LITERATURE REVIEW}

Several studies have recommended that the utilization of modern technology in classrooms is essential for students to succeed in the Internet era (Bingimlas, 2009; Alshumaimeri \& Bamanger, 2013). According to Marwan (2008), many educational institutions worldwide have integrated the use of computer technology with teaching, providing numerous benefits. For example, teachers have created visualizations of abstract concepts along with real-world simulations using the latest technology, reducing the class time needed for explanations. However, even though some teachers have used the latest technology, the majority still use traditional methods (Solanki, 2012).

Quite a few studies have examined the integration of technology in English language classes (Ismail, Almekhlafi, \& Al-Mekhlafy, 2010; Bamanger \& Alhassan, 2015; Alshumaimeri, Gashan, \& Bamanger, 2019). Lee (2000) noted the many benefits from integrating technology into education, such as sharpening students' linguistic skills through its positive impact on their learning attitudes, enhancing self-instruction strategies helping students gain access to authentic educational material and research papers that show a wide range of English usage.

Teachers have played a significant role in ensuring technology integration when educational institutions make investments in infrastructure (Marwan, 2008), although they have faced barriers (Salehi \& Salehi, 2012). Successful integration depends on several factors, depending on the educational environment and the purpose and timing of the introduction (Alwani \& Soomro, 2010). Many studies have investigated the barriers hindering the integration of technology with education (Alwani \& Soomro, 2010; Bingimlas, 2009; Darus \& Luin, 2008; Groff \& Mouza, 2008; Ismail, 2010; Jacobsen, 1998; Kabilan \& Rajab, 2010; Khan, Hasan, \& Clement, 2012; Lee, 2000; Lu, 2006; Marwan, 2008; Olowa, 2012; Salehi \& Salehi, 2012; and Semary, 2011).

Salehi and Salehi $(2012$, p. 218) noted that the act of integrating ICT into teaching and learning is a complex and difficult process. Researchers have classified the barriers into two broad categories: extrinsic and intrinsic (Almalki \& Williams, 2012; Bingimlas, 2009; Salehi \& Salehi, 2012). Jones (2004) wrote that external barriers include a lack of access to resources, a lack of time, a lack of effective training, and technical problems. The internal barriers include a lack of confidence, resistance to change, and the negative perception of no benefits.

Ertmer (1999, p. 52, as cited in Earle, 2002) has classified barriers into two main categories: first-order barriers that are extrinsic to teachers, such as access, time, support, resources, and training, and second-order barriers that are intrinsic to teachers such as attitudes, beliefs, practices, and resistance. Accordingly, Akcaoğlu (2008) pointed out that first-order barriers (e.g., computer hardware) are beyond teachers' control, while second-order barriers result from personal factors (e.g., competence, attitude, and beliefs). As asserted by Lee (2000), the barriers that inhibit the practice of computer-assisted language learning (CALL) break into four common categories: financial barriers, availability of computer hardware and software, technical and theoretical knowledge, and acceptance of the technology.

Several studies have concentrated on the major barriers that hinder teachers from using technology in education. According to Bingimlas (2009), "lack of confidence amongst teachers, lack of teachers' competence, resistance to change, negative attitudes, lack of time, lack of effective training, lack of accessibility, and the lack of technical support are major difficulties that have prevented teachers from integrating technology into teaching" (pp. 237-241). Salehi and Salehi (2012, p. 218) claimed that insufficient technical support at schools and little access to the Internet have prevented teachers from using ICT in the classroom, in addition to a shortage of class time and the learning curve for using ICT. According to Marwan (2008), the absence of adequate help or technical support to facilitate technology-mediated teaching is another factor that hinders adoption, and Earle (2002) also mentioned restraining forces such as lack of technical support, teacher expertise, time for planning, and pedagogical applications.

\section{Technology in Saudi Arabia}

Before January 1999, internet access was not available in Saudi Arabia. The only access was through other Gulf countries such as Bahrain or the UAE. As time went on, most Saudi industries began to depend on email and internet-based networks for their day-to-day businesses (Al-Maliki, 2013). Because internet access is a critical element of progress for ICT and necessary for organizations to work effectively (Almalki \& Williams, 2012, p. 42) promotion of ICT has been a top priority (Al-Maliki, 2013; Alshumaim \& Alhassan, 2010). The Saudi government invested millions of 
dollars in education to improve the country's status in computer use and the internet (Alharbi, 2013, p.10), but technology integration into education has faced many barriers in Saudi Arabia. The top issue has involved keeping up to date as technology advances, which demands increasing human resources, money, and time (Al-Maliki, 2013). As a developing country, Saudi Arabia does not have technology infrastructure on par with the developed countries (Almalki and Williams, 2012, p. 42 Alshumaimeri, 2019), and there is an overall lack of research concerning the obstacles that hinder the implementation of ICT (Almaliki, 2013).

\section{Teachers' Beliefs}

The research literature shows that attitudes in teaching and learning are an essential element for technology integration (Mumtaz, 2000) and often play a vital role in the achievement of educational aims (Alshumaimeri, 2008). Oyaid (2009) found a positive relationship between teachers' ICT use and their perceptions towards computers, but it is often the case that teachers' positive attitudes do not imply that they have used technology in their classroom (Egbert, Paulus, \& Nakamichi, 2002; Gashan \& Alshumaimeri, 2015). Al-Mekhlafi (2004) and Ageel (2011) confirmed this fact and found that most of the participants did not make use of ICT in their teaching, even though they were interested in learning about and undergoing training in ICT.

Almalki and Williams (2012, p. 44) asserted that teachers who enthusiastically sought to develop their learning processes were more likely to integrate technology into their teaching. However, according to Oyaid (2009), many factors have impacted this relationship, including motivators, incentives, and supporting factors, as well as constraints that hindered the use of ICT. Boulter (2007) also noted that there are many factors related to teachers' use of technology, including modeling by colleagues, school administration expectations, access, positive experiences with computers in teaching, and teachers' beliefs and attitudes about technology in teaching. Moreover, Okojie, Olinzock, and Okojie-Boulder (2006) argued that a lack of guidelines limits teachers' uses of technology and influences their desire for its usage, and they contended that teachers with no understanding of the purpose of integrating technology into teaching might not succeed in the classroom. Egbert, Paulus, and Nakamichi (2002) mentioned that teachers' attitudes and beliefs toward using technology in teaching may aid or prevent the usage of ICT in the classroom.

Many studies have indicated that teachers have positive perceptions of using technology in teaching. Oyaid (2009) found that confident teachers expressed positive attitudes towards ICT, while less confident teachers expressed negative attitudes. A possible explanation was the effect of teachers' computer competence on attitudes. Muir-Herzig (2004) asserted that, with this competence, anxiety decreases, and positive attitudes develop with more computer literacy courses.

In a study conducted in the United Arab Emirates, Ismail, Almekhlafi, and Al-Mekhlafy (2010) found that teachers had positive attitudes towards integrating technology into teaching. The findings indicated that the most significant factor that prevented ICT integration was the lack of time for teachers to prepare and implement ICT. Dashtestani (2012) discovered that Iranian EFL teachers had encouraging attitudes towards CALL, although there were several barriers, as well. These included external factors such as a lack of computer-based facilities, time, financial and technical support, and adequate teacher training programs, as well as rigid curricula; internal factors included teachers' lack of knowledge, resources, experience, and access to CALL-based material. Similarly, in a study conducted in South Korea, Park and Son (2009) found that teachers had positive attitudes toward technology. They reported that external factors such as lack of time, insufficient computer facilities, rigid school curricula, and textbooks, and lack of administrative support negatively affected the implementation of CALL in the classroom. Internal factors such as teachers' limited computer skills and knowledge about computers, as well as beliefs and perceptions about CALL, also influenced teachers' decisions on its use.

Nor and Vasu (2010) put forth that Malaysian teachers held positive feelings about CALL lessons, though problems with facilities and with teachers' attitudes were constraints that hindered implementation. Hamed and Devi (2011) investigated Libyan English language teachers' attitudes toward integrating technology into teaching. Their findings revealed that most of the teachers had positive attitudes toward this integration though they faced problems related to time constraints and lack of administrative support.

Oyaid (2009) has maintained that, as a developing country, Saudi Arabia has had little experience with ICT usage in education because it started implementation in secondary schools after 2000. In general, little research exists about ICT usage in Saudi Arabia. In contrast, many Western studies have concentrated on the factors that support teachers' implementation of ICT and the barriers hindering its usage, and these studies have been helpful in providing insights for developing ICT usage in Saudi Arabia. In the studies of teacher attitudes toward ICT that do exist for secondary schools, those teachers noted many barriers that have hindered their usage of ICT, including a) access, b) time, c) training, d) equipment, and e) technical support. Teachers have suggested comprehensive development for the future as related to curriculum, teacher training, and education as methods to overcome these barriers. In another study, Aytekin, AbdulAziz, Barakat, and Abdelrahman (2012) determined that Saudi secondary school teachers have positive attitudes toward the use of the interactive whiteboard, although only a few have had successes in the classroom.

Alshumaimeri (2008) discovered a clear-cut relationship between a teacher's attendance during training and constructive attitudes towards the use of ICT in the Saudi classroom, both for computers and for CALL. Alharbi (2013) probed teachers' attitudes and barriers towards integrating technology in Saudi Arabia and the United States, finding that teachers from both countries held upbeat attitudes toward technology integration in education, though there were differences in teacher preparation for using technology. There were also differences related to the availability of technology 
in classrooms. Time constraints were one of the most important barriers that hindered the use and integration of ICT in the curriculum.

Similarly, many other studies conducted on this issue have revealed a common pattern of findings. Al-Sulaimani (2010) found that teachers had positive attitudes towards ICT integration into the science curriculum of intermediate schools in the Kingdom of Saudi Arabia, although the barriers to classroom use included time constraints, insufficient ICT course material, and inadequate access to external training for women teachers.

\section{Enhancing the use of ICT in Teaching}

Almalki and Williams (2012) suggested that comprehensive planning is vital to overcome problems such as the lack of funding support, coping with different local cultures, and the lack of effective training. The authors pointed out that the lack of success in the adoption of ICT strategies in Saudi Arabia could relate to the fact that ICT came from developed countries that have a different culture. Earle (2002) argued that the driving forces for ICT integration include the power and the potential of new developments, rapid availability, creativity, internet access, ease of communication, and its promised impact on learning. Muir-Herzig (2004, p. 116) noted that training historically focused on how to use the equipment instead of how teachers should integrate technology into their curriculum. Earle (2002) also recognized this and recommended that the goal should be to ensure that content is taught more effectively, with technology as a tool to support teaching and learning.

\section{RESEARCH DESIGN}

The goal of this research was to quantify Saudi English teachers' perceptions about the use of ICT in classroom education, identify some of the barriers hindering such use, and gathering suggestions about classroom use. This study was both quantitative and qualitative. The justification for using both approaches was based on the assertation by Cohen, Manion, and Morrison (2010, p. 143) that, "triangular techniques are suitable when a more holistic view of educational outcomes is sought."

The most suitable way to explore these issues was to use data collection tools, usually associated with the qualitative approach (Oyaid, 2009). The questionnaire used in this study incorporated a five-point Likert scale and had open-ended questions to gain a better understanding of the issues.

The rationale for using a questionnaire was to obtain generalizable results. The self-administered questionnaires produced a larger sample as compared to the interview method (Oyaid, 2009). The justification for using open-ended questions as qualitative data was that this approach aided in gaining an understanding of the perspective of educational practitioners regarding ICT usage in education.

\section{Study Population and Participants}

The research population included secondary English teachers in Al-Jouf education district in Saudi Arabia, 43 secondary boys' schools, and 46 secondary girls' schools. The number of schools that responded equaled 67, which represents almost a third of the total population. The total number of secondary English teachers at Al-Jouf education district at the time of the survey was 201 (62=male, 139= female)

A sample of 76 secondary English teachers took part in the study and completed the questionnaire for a response rate of $38 \%$. The sample included 35 males $(46.1 \%)$ and 41 females $(53.9 \%)$. Thirty-seven $(48.7 \%)$ participants were between 20-30 years old, and 31 (40.8\%) were between 30-40 years old. Only $8(10.5 \%)$ participants were more than 40 years of age. Most participants (54.8\%) held a bachelor's degree, $9.6 \%$ were postgraduates, and $2.7 \%$ had doctorate level qualifications. In addition, $38.4 \%$ of participants were qualified in English teaching, and 9.6\% had a special qualification in teaching.

None of the participants had qualifications in ICT. 31.6\% of the participants had 10-14 years' teaching experience, while $28.9 \%$ of the participants had less than 5 years teaching experience, $21.1 \%$ had 5-9 years teaching experience, $11.8 \%$ had $15-19$ years teaching experience, and only $6.6 \%$ had more than 20 years teaching experience.

An overwhelming majority (93.3\%) had personal computers/laptops/tablets at home for their own use. Likewise, a large majority of the participants (78.7\%) stated that the average number of students in their classes exceeded 20. The remaining survey participants $(21.3 \%)$ had fewer than 20 students in their class. Finally, $63.5 \%$ of teachers had attended training courses about using technology in teaching.

\section{The Research Instrument}

Questionnaires, popular in the practice of educational research, have helped researchers obtain generalizable results. However, limitations such as ambiguity and the possibility of misunderstanding exist in all such efforts. Further, questionnaire design has proven to be a research variable of its own for many studies. Past practice was that there should be a minimal number of questions included, but it was also true that reducing the number of questions affected the results (Oyaid, 2009).

The first draft of the questionnaire originated from similar survey questions found in the research literature. Then the draft underwent revision according to the comments received from two EFL experts regarding relevance and clarity. The questionnaire consisted of five sections with a total of fifty individual questions, all in English. The first section requested the participants' demographic data. The second section examined EFL teachers' perceptions on integrating technology into English language teaching within the ALJouf education district. The third section investigated EFL teachers' perceptions concerning barriers to technology integration. The fourth section had questions asking for EFL teachers' suggestions to overcome the barriers. Sections 2 -4 used the Likert scale ( $5=$ strongly agree, $4=$ agree, $3=$ neutral, $2=$ disagree, $1=$ strongly disagree). In contrast, the fifth section included only open-ended questions to further explore the perceptions and opinions of the participants regarding technology integration. 


\section{Implementation}

The authors sent a letter and the questionnaire to Al-Jouf education authority, informing them about the aims of the study and requesting cooperation. Al-Jouf education authority, in turn, sent letters to 89 schools asking them to take part in the research. The questionnaire arrived by mail at the schools on March 30, 2018. By April 20, 2018, all participants had returned completed surveys by mail.

Cronbach's Alpha Coefficient of the questionnaire served as the primary measure of consistency. The calculated value was 0.891 , which suggested high reliability. Two academicians specializing in EFL at King Saud University reviewed the validity of the questionnaire and deemed it to be proper.

\section{Data Analysis}

An essential step in any research, data analysis, transforms the raw data obtained from questionnaires into meaningful information. The procedures to carry out this transformation needed to be suitable for the research questions (Oyaid, 2009).

The Statistical Package for Social Sciences (SPSS, version 16.0) was the primary analysis tool. The first step included a descriptive analysis of the data from the closed questions such as frequencies, percentages, means, and standard deviation. The open-ended items of the questionnaire were subject to content and descriptive analysis. It is pertinent to mention that open-ended questions had few responses. Based on interviews, it became clear that teachers believed that the closed questions covered everything.

\section{RESEARCH RESULTS AND DISCUSSION}

This section details the tabulated results of the study. The first part of each sub-section lists the general theme. The subsequent tables show the results for each question based on the Likert scale.

\section{Teachers' Perceptions Toward Integrating Technology into English Language Teaching}

What, according to secondary English teachers at Al-Jouf education district in Saudi Arabia, are the benefits of the use of technology in English teaching? (12 statements - see Table 1)

For Table 1, the mean score for the first section of the questionnaire was 4.37. This showed that the participants had strong positive attitudes towards integrating technology into English language teaching. For example, almost all $(94.6 \%)$ agreed that "Using technology increases the options for methods and strategies for teaching."

The other three statements that had high agreement levels included: "Using technology improves access to related information for teachers and students" (92\%), "I am interested in going for a training course on how to use technology in teaching the English language" (90.7\%), and, "Using technology in teaching the English language motivates students to learn the language" $(89.5 \%)$. All statements attracted an agreement level of more than $(80 \%)$.

\section{Teachers' Perceptions Towards Technology Integration Barriers}

What are the barriers that prevent secondary English teachers at the AL-Jouf education district in Saudi Arabia from using technology in teaching? (18 statements - see Table 2)

Table 2. Secondary English teachers' perceptions towards the barriers that prevent the use of technology in teaching.

As illustrated by Table 2, all the statements had agreement levels of at least $50 \%$, and fourteen of the eighteen statements had agreement levels of more than $60 \%$. A holistic view revealed that three main factors prevented teachers' use of ICT: a) lack of training courses about ICT, b) infrastructure issues, and c) lack of technology resources.

To gain more in-depth information, the teachers were asked to respond in writing if they considered other factors as barriers hindering the use of ICT in classrooms. Based on their responses, the lack of technology resources, a substantial number of students in the class, and small classrooms were the top three hindrances. Teachers also mentioned that lack of knowledge and skills regarding ICT use, students' resistance to ICT use, and the low achievement level of students hindered them from using ICT for instruction. Moreover, the lack of training courses, time constraints, curriculum, the resistance of teachers, and managerial issues were other obstacles mentioned by the teachers.

\section{Teachers' Suggestions to Overcome the Barriers}

What, according to the teachers, are the steps that can be taken by the stakeholders (government, school authorities, teachers, students, and parents) to overcome these barriers? (13 statements - see Table 3)

Table 3. Secondary English teachers' perceptions towards the steps which can be taken by the stakeholders to overcome the barriers.

As is clear from table 3, all the statements attracted agreement levels of more than $70 \%$, and five of the thirteen attracted agreement levels over 90\%. Teachers perceived three suggestions as to the most important steps for overcoming the barriers:

1. "The overall vision and strategy for the use of technology in education should be made more explicit, and should be communicated to teachers" (90\%),

2. "Create physical infrastructure (labs, classrooms)" $(91.8 \%)$, and

3. "Encourage teachers by providing adequate incentives for implementing technology in teaching" (91.7\%).

To gain a better understanding, Section 4 asked teachers to give written suggestions about what steps could overcome these challenges. Based on the responses, it was clear that financial issues were important for the use of ICT because some schools did not have labs or had old equipment. Other participants emphasized the necessity to change the curriculum to make it conducive to the use of IT. One participant suggested that teaching students with ICT from an early age would be useful in the later stages. Other participants believed that reducing the number of students in the class, 
Table 1. Secondary English teachers' perceptions towards the benefits of using technology in English teaching.

\begin{tabular}{|c|c|c|c|c|c|c|c|c|}
\hline Statement & $\begin{array}{c}\text { Agree } \\
\text { combined \% }\end{array}$ & $\begin{array}{l}\text { Strongly } \\
\text { agree \% }\end{array}$ & $\begin{array}{c}\text { Agree } \\
\%\end{array}$ & $\begin{array}{c}\text { Neutral } \\
\%\end{array}$ & $\begin{array}{c}\text { Disagree } \\
\%\end{array}$ & $\begin{array}{c}\text { Strongly } \\
\text { disagree \% }\end{array}$ & Mean & $\begin{array}{l}\text { Std. } \\
\text { Dev. }\end{array}$ \\
\hline $\begin{array}{l}\text { 1-Using technology increases the } \\
\text { options for methods and strategies } \\
\text { for teaching (e.g., audio files for } \\
\text { pronunciation) }\end{array}$ & 94.6 & 59.5 & 35.1 & 5.4 & 0 & 0 & 4.54 & 0.60 \\
\hline $\begin{array}{l}\text { 2-Using technology improves access } \\
\text { to related information for teachers } \\
\text { and students. }\end{array}$ & 92 & 65.3 & 26.7 & 8.0 & 0 & 0 & 4.57 & 0.64 \\
\hline $\begin{array}{l}\text { 3-I am interested in going for a } \\
\text { training course on how to use } \\
\text { technology in teaching the English } \\
\text { language. }\end{array}$ & 90.7 & 60.0 & 30.7 & 9.3 & 0 & 0 & 4.50 & 0.66 \\
\hline $\begin{array}{l}\text { 4-Using technology in teaching } \\
\text { English language motivates students } \\
\text { to learn the language. }\end{array}$ & 89.5 & 59.2 & 30.3 & 9.2 & 1.3 & 0 & 4.47 & 0.72 \\
\hline $\begin{array}{l}\text { 5-Using technology is important for } \\
\text { teaching different English language } \\
\text { skills. }\end{array}$ & 89.2 & 51.4 & 37.8 & 9.5 & 1.4 & 0 & 4.39 & 0.71 \\
\hline $\begin{array}{l}\text { 6-Using technology in English } \\
\text { language teaching saves teachers' } \\
\text { time and effort. }\end{array}$ & 88.1 & 51.3 & 36.8 & 10.5 & 0 & 1.3 & 4.36 & 0.78 \\
\hline $\begin{array}{l}\text { 7-Using technology facilitates the } \\
\text { English language teaching process } \\
\text { (makes it interactive). }\end{array}$ & 88 & 49.3 & 38.7 & 12 & 0 & 0 & 4.37 & 0.69 \\
\hline $\begin{array}{l}\text { 8-Using technology facilitates } \\
\text { collaborative learning / project } \\
\text { work. }\end{array}$ & 88 & 30.7 & 57.3 & 12 & 0 & 0 & 4.18 & 0.63 \\
\hline $\begin{array}{l}\text { 9-Using technology is effective as } \\
\text { it helps teachers to assess students } \\
\text { accurately. }\end{array}$ & 86.8 & 42.1 & 44.7 & 11.8 & 1.3 & 0 & 4.27 & 0.72 \\
\hline $\begin{array}{l}\text { 10-Using technology promotes } \\
\text { English teachers' professional } \\
\text { development. }\end{array}$ & 85.3 & 48.0 & 37.3 & 12 & 1.3 & 1.3 & 4.29 & 0.83 \\
\hline $\begin{array}{l}\text { 11-Using technology improves } \\
\text { students' English language } \\
\text { achievement. }\end{array}$ & 85.1 & 44.6 & 40.5 & 10.8 & 4.1 & 0 & 4.25 & 0.81 \\
\hline $\begin{array}{l}\text { 12-Using technology enhances } \\
\text { students' English language learning. }\end{array}$ & 84.3 & 45.7 & 38.6 & 14.3 & 1.4 & 0 & 4.28 & 0.76 \\
\hline
\end{tabular}

offering training courses, improving the quality and quantity of support staff, awareness-raising workshops for both teachers and students, increasing class duration, and offering incentives to students to use technology in the classroom could play an important part in the development of ICT use in English teaching. As a last point, one response included the suggestion that the building of infrastructure could enhance the use of English media for instruction such as news broadcasts, or audiobooks.

\section{DISCUSSION OF THE RESULTS}

An important response was that $93.3 \%$ of the participants had personal computers /laptops or tablets at home for their own use. This high percentage revealed that most teachers were familiar with the technology. The results of this study also indicated that secondary English teachers had positive attitudes toward technology integration in English teaching. This is a key factor for the use of technology in education (Dashtestani, 2012).

Furthermore, Oyaid (2009) noted that teachers with positive attitudes are more comfortable using ICT. As such, ICT has the potential to change the ways of teaching (Almaliki $\&$ Williams, 2012). The teachers who took part in this study were keen on using technology in teaching because they thought it could help them perform their duties more effectively. This is consistent with other findings that teachers believe the use of technology increases the options for methods and strategies for teaching and improves access to extra information.

The eagerness for using ICT in education was apparent by the interest expressed in training. Even the participants 
Table 2. Secondary English teachers' perceptions towards the barriers that prevent the use of technology in teaching

\begin{tabular}{|c|c|c|c|c|c|c|c|c|}
\hline Statement & $\begin{array}{c}\text { Agree } \\
\text { combined \% }\end{array}$ & $\begin{array}{l}\text { Strongly } \\
\text { agree } \%\end{array}$ & $\begin{array}{c}\text { Agree } \\
\%\end{array}$ & $\begin{array}{c}\text { Neutral } \\
\%\end{array}$ & $\begin{array}{c}\text { Disagree } \\
\% \\
\end{array}$ & $\begin{array}{c}\text { Strongly } \\
\text { disagree \% }\end{array}$ & Mean & $\begin{array}{l}\text { Std. } \\
\text { Dev. }\end{array}$ \\
\hline $\begin{array}{l}\text { 1-Lack of teacher training courses } \\
\text { about using technology in teaching } \\
\text { the English language. }\end{array}$ & 84 & 22.7 & 61.3 & 9.3 & 6.7 & 0 & 4.00 & 0.77 \\
\hline $\begin{array}{l}\text { 2-Architecture of the classroom } \\
\text { is not suitable, or there is no } \\
\text { specific auditorium or lab for } \\
\text { IT (instructional technology) } \\
\text { integrated education. }\end{array}$ & 77.3 & 40 & 37.3 & 17.3 & 5.3 & 0 & 4.12 & 0.88 \\
\hline $\begin{array}{l}\text { 3-Lack of technology resources } \\
\text { (e.g., computers, IPad, projectors, } \\
\text { internet) at schools for teachers. }\end{array}$ & 70.2 & 32.4 & 37.8 & 9.5 & 16.2 & 4.1 & 3.78 & 1.18 \\
\hline $\begin{array}{l}\text { 4-Maintenance of the available } \\
\text { equipment is poor, or the } \\
\text { equipment / software is outdated. }\end{array}$ & 69.4 & 23.6 & 45.8 & 19.4 & 11.1 & 0 & 3.81 & 0.92 \\
\hline $\begin{array}{l}\text { 5-Lack of vision for use of } \\
\text { technology in education or policy } \\
\text { support from government / } \\
\text { administrators. }\end{array}$ & 68.5 & 21.1 & 47.4 & 13.2 & 14.5 & 3.9 & 3.67 & 1.08 \\
\hline $\begin{array}{l}\text { 6-Shortage of time needed for } \\
\text { lesson preparation. }\end{array}$ & 68 & 25.3 & 42.7 & 17.3 & 12 & 2.7 & 3.76 & 1.05 \\
\hline $\begin{array}{l}\text { 7-Teachers do not have updated } \\
\text { knowledge of the possibilities } \\
\text { which exist for using ICT } \\
\text { (information and communication } \\
\text { technology) in their teaching } \\
\text { process. }\end{array}$ & 64 & 12 & 52 & 20 & 9.3 & 6.7 & 3.53 & 1.04 \\
\hline $\begin{array}{l}\text { 8-Lack of time needed for the } \\
\text { implementation of technology in } \\
\text { the classroom. }\end{array}$ & 63.5 & 25.7 & 37.8 & 24.3 & 10.8 & 1.4 & 3.75 & 1.00 \\
\hline $\begin{array}{l}\text { 9-Lab equipment is not sufficient to } \\
\text { meet the students' needs. }\end{array}$ & 63.5 & 18.9 & 44.6 & 17.6 & 18.9 & 0 & 3.63 & 1.00 \\
\hline $\begin{array}{l}\text { 10-Curriculum in schools at this } \\
\text { level is not conducive to the use of } \\
\text { IT in English teaching }\end{array}$ & 63.2 & 21.1 & 42.1 & 21.1 & 11.8 & 3.9 & 3.64 & 1.06 \\
\hline $\begin{array}{l}\text { 11-No incentives for teachers to } \\
\text { use technology in their classrooms. }\end{array}$ & 62.9 & 30 & 32.9 & 21.4 & 14.3 & 1.4 & 3.75 & 1.08 \\
\hline $\begin{array}{l}\text { 12-Non-availability of suitable } \\
\text { technological equipment/software } \\
\text { in the local market for teaching the } \\
\text { English language. }\end{array}$ & 62.7 & 24 & 38.7 & 14.7 & 18.7 & 4 & 3.60 & 1.16 \\
\hline $\begin{array}{l}\text { 13-Assessment system in these } \\
\text { schools at this level is not } \\
\text { conducive to the use of IT in } \\
\text { English teaching. }\end{array}$ & 60.6 & 21.1 & 39.5 & 26.3 & 10.5 & 2.6 & 3.65 & 1.01 \\
\hline $\begin{array}{l}\text { 14-Lack of teachers' knowledge } \\
\text { and skills in using technology for } \\
\text { teaching the English language. }\end{array}$ & 60 & 14.7 & 45.3 & 21.3 & 17.3 & 1.3 & 3.54 & 0.99 \\
\hline $\begin{array}{l}15 \text {-Students' motivation to } \\
\text { integrate technology into teaching } \\
\text { is too low. }\end{array}$ & 59.4 & 21.6 & 37.8 & 10.8 & 25.7 & 4.1 & 3.47 & 1.20 \\
\hline $\begin{array}{l}\text { 16-Inadequate number of technical } \\
\text { support staff available. }\end{array}$ & 57.5 & 12.3 & 45.2 & 24.7 & 13.7 & 4.1 & 3.47 & 1.01 \\
\hline $\begin{array}{l}\text { 17-Teachers' resistance to the use } \\
\text { of technology in teaching. }\end{array}$ & 50 & 11.4 & 38.6 & 21.4 & 21.4 & 7.1 & 3.25 & 1.13 \\
\hline $\begin{array}{l}\text { 18-Parents' resistance to the use of } \\
\text { technology in teaching. }\end{array}$ & 50 & 8.6 & 41.4 & 15.7 & 22.9 & 11.4 & 3.12 & 1.20 \\
\hline
\end{tabular}


Table 3. Secondary English teachers' perceptions towards the steps which can be taken by the stakeholders to overcome the barriers

\begin{tabular}{|c|c|c|c|c|c|c|c|c|}
\hline Statement & $\begin{array}{c}\text { Agree } \\
\text { combined \% }\end{array}$ & $\begin{array}{l}\text { Strongly } \\
\text { agree } \%\end{array}$ & $\begin{array}{l}\text { Agree } \\
\%\end{array}$ & $\begin{array}{c}\text { Neutral } \\
\%\end{array}$ & $\begin{array}{l}\text { Disagree } \\
\%\end{array}$ & $\begin{array}{c}\text { Strongly } \\
\text { disagree\% }\end{array}$ & Mean & $\begin{array}{l}\text { Std. } \\
\text { Dev. }\end{array}$ \\
\hline $\begin{array}{l}\text { 1-The overall vision and strategy for } \\
\text { the use of technology in education } \\
\text { should be made more explicit and } \\
\text { should be communicated to teachers. }\end{array}$ & 92 & 41.3 & 50.7 & 6.7 & 0 & 1.3 & 4.30 & 0.71 \\
\hline $\begin{array}{l}\text { 2-Create physical infrastructure (labs, } \\
\text { classrooms) }\end{array}$ & 91.8 & 45.2 & 46.6 & 6.8 & 1.4 & 0 & 4.35 & 0.67 \\
\hline $\begin{array}{l}\text { 3-Encourage teachers by providing } \\
\text { adequate incentives for implementing } \\
\text { technology in teaching. }\end{array}$ & 91.7 & 41.7 & 50 & 6.9 & 1.4 & 0 & 4.31 & 0.66 \\
\hline $\begin{array}{l}\text { 4-Providing training to the technical } \\
\text { support staff from time to time. }\end{array}$ & 90.4 & 45.2 & 45.2 & 9.6 & 0 & 0 & 4.35 & 0.65 \\
\hline $\begin{array}{l}\text { 5-Improving the quality and quantity } \\
\text { of support staff. }\end{array}$ & 90.3 & 38.9 & 51.4 & 8.3 & 1.4 & 0 & 4.27 & 0.67 \\
\hline $\begin{array}{l}\text { 6-Funding schools to purchase the } \\
\text { required equipment \& software. }\end{array}$ & 86.5 & 32.4 & 54.1 & 9.5 & 2.7 & 1.4 & 4.13 & 0.79 \\
\hline $\begin{array}{l}\text { 7-Making changes to the curriculum } \\
\text { to make it conducive to education } \\
\text { through ICT. }\end{array}$ & 86.4 & 40.5 & 45.9 & 10.8 & 2.7 & 0 & 4.24 & 0.75 \\
\hline $\begin{array}{l}\text { 8-Making changes to the assessment } \\
\text { system to make it conducive to } \\
\text { education through ICT. }\end{array}$ & 86.4 & 37.8 & 48.6 & 13.5 & 0 & 0 & 4.24 & 0.67 \\
\hline $\begin{array}{l}\text { 9-Teacher training and education } \\
\text { programs should include courses, } \\
\text { which concentrate on technology } \\
\text { integration into teaching. }\end{array}$ & 85.4 & 50.7 & 34.7 & 9.3 & 5.3 & 0 & 4.30 & 0.85 \\
\hline $\begin{array}{l}\text { 10-Organizing workshops for } \\
\text { teachers \& Students on the benefits } \\
\text { of integration and the latest trends. }\end{array}$ & 84 & 42.7 & 41.3 & 14.7 & 1.3 & 0 & 4.25 & 0.75 \\
\hline $\begin{array}{l}\text { 11-Increase interaction with parents } \\
\text { to help them understand the benefits } \\
\text { of the use of IT in education. }\end{array}$ & 81.1 & 31.1 & 50 & 18.9 & 0 & 0 & 4.12 & 0.70 \\
\hline $\begin{array}{l}\text { 12-Private firms should be invited } \\
\text { periodically (say, once in } 6 \text { months) } \\
\text { to visit the schools and interact with } \\
\text { the teachers \& students to update } \\
\text { them of their offerings. }\end{array}$ & 80 & 30.7 & 49.3 & 17.3 & 1.3 & 1.3 & 4.06 & 0.81 \\
\hline $\begin{array}{l}\text { 13-Increase class timings to help } \\
\text { teachers in using technology in } \\
\text { teaching English. }\end{array}$ & 74.3 & 32.4 & 41.9 & 17.6 & 8.1 & 0 & 3.98 & 0.91 \\
\hline
\end{tabular}

above 40 years of age had positive attitudes towards the integration (agreement level of $>84 \%$ mean score of 4.3 ). Moreover, these findings were similar to the results of other studies (Ackoaglu, 2008; Ageel, 2011; Alsulimani, 2010; Aytekin, AbdulAziz, Barakat, \& Abdelrahman, 2012; Dashtestani, 2012; Hamad \& Devi, 2011; Ismail et al., 2010; Nor \& Vasu, 2010; Oyaid, 2009; Park \& Son, 2009).

Oyaid (2009) asserted that knowing the reasons for teachers' existing levels of ICT usage is important. This knowledge helps in attempts to maximize or minimize the factors supporting or hindering its use. In this study, the teachers mentioned some hindrances that affected their ICT use in classroom teaching. Lack of teacher training courses, infrastructure issues, and lack of technology resources were the three main factors.

Almalki and Williams (2012) emphasized the importance of good training for teachers to improve teacher competence and skill in ICT, as opposed to a lack of proper training or a shortage of time for training, an inappropriate training program, lack of training in the newest technology, or lack of pedagogical training. The high agreement level on questions indicating lack of training as the main barrier suggested that teachers may not have the required skills or knowledge to integrate technology into their lessons. Alshumaimri (2008) argued that the increased use of technology tools necessitates a change in the epistemology for today's teachers. 
Continuous ICT training helps overcome many hindrances and can keep teachers motivated and capable of handling the problems they may encounter. Moreover, training held in the schools should ensure that attendance is good and that teachers' awareness and acceptance level for the use of ICT increases. The findings of this study were like the results obtained in several other studies (Alshumaimri \& Alhassan, 2010; Boulter, 2007; Oyaid, 2009).

Other factors that hinder ICT implementation are related to a lack of infrastructure and financial difficulties. Hakami et al. (2013) pointed out that ICT infrastructure and resources in most schools are insufficient, considering the number of students. Some schools do not even have an English lab, and the available equipment is outdated. Other teachers from the present study mentioned that small classrooms hindered the use of ICT. The teachers in Akcaoğlu's study (2008) perceived the lack of infrastructure as one of the major factors hindering ICT usage.

The teachers in the current study indicated that the infrastructure and the lack of technology resources prevented ICT usage in the classroom. Almalki and Williams (2012) also pointed out that deficiencies in software and hardware infrastructure in schools may be a result of insufficient funds, and funding for technology resources is necessary for effective use of ICT equipment such as computers, projectors, CDs, videos, and laptops. Shortages on this account have a negative impact on ICT implementation. Akcaoğlu (2008) asserted that even if teachers have basic computer skills and positive attitudes, this may not contribute to high instructional computer usage if they lack access to technology. These findings correspond to the results obtained in other studies such as Alshumaim and Alhassan (2010), Boulter (2007), Dashtetani (2012), Egbert et al. (2002), Lu (2006), and Oyaid (2009).

Other important barriers that are evident from this study include the lack of maintenance and obsolete software/ equipment, lack of vision for the use of technology in education from administrators, and the shortage of time. Almalki and Williams (2012) also highlighted the importance of adequate time to prepare for ICT implementation. Large numbers of students in a class, small classrooms, lack of knowledge and skills regarding ICT use, students' resistance and their low achievement level, rigid curriculum, teachers' resistance, and managerial issues were other barriers noted by teachers in this study.

Regarding the suggestions from Saudi English teachers for improving the status of technology integration in teaching, the participants call strategies mentioned in the questionnaire as extremely important. This was evident from the fact that the agreement level for all items surpassed $74 \%$. The most important steps were in the realm of administrators and stakeholders. They need to make the overall vision and strategy for the use of technology in education more explicit. This finding is consistent with the views of Almaliki and Williams (2012) who maintained that successful ICT integration requires good planning. Khan et al. (2012) argued that effective implementation of ICT in education is not just about the vision, but needs proper planning, execution, and monitoring. In this study, the teachers agreed that creating physical infrastructure was one of the important steps to execute this integration effectively. Alshumaim and Alhassan (2010) put forth that schools could inadvertently block ICT development due to incoherent plans for its inclusion. The teachers in the current study also suggested that adequate teaching incentives for using technology would bring increased adoption.

\section{CONCLUSION AND IMPLICATIONS}

The use of technology in education has been an important research topic for several decades prior to this study. The benefits of using ICT in teaching and learning are well known. However, based on the results of this study, creating a suitable ICT environment has been challenging for teachers, students, and principle authorities.

The findings revealed that teachers perceived the use of ICT in teaching positively. They also identified several hindrances to practical use. External factors were the major barriers revealed in this study. The top three hindrances were the lack of teacher training, inadequate infrastructure, and the lack of technology resources. Accordingly, the suggested improvements from English Language teachers included making the overall vision and strategy for ICT use explicit, improving the availability of physical infrastructure, and providing adequate incentives to the teachers.

In conclusion, educational authorities should make efforts to eliminate the external barriers identified, and they should take teachers' suggestions into account to improve the use of ICT in teaching. This will further enhance the positive attitudes of the teachers. In addition, teachers should have clear plans and procedures to enable them to achieve ICT integration. The importance of ICT training courses for facilitating technology integration becomes critical. Training will increase the teachers' confidence and competency levels and increase awareness of the benefits of ICT and the skills required for its integration. Improving teachers' technology literacy will positively affect future ICT use in the classroom.

\section{Further Research}

The following suggestions are for researchers in the educational field to help them gain better insights into the issues related to using ICT in teaching in the context of additional potential studies:

1. Identification of the most appropriate methods and strategies for integrating technology into teaching.

2. Combination of the use of questionnaires with other methods, such as observation and interview. This could provide more in-depth insight into teachers' perceptions of factors supporting and hindering the use of ICT in education.

3. A focus on the types of technology literacy skills that are relevant to English language teaching.

4. Measurement of the learning curve effects for teachers deploying innovative technology.

\section{ACKNOWLEDGMENTS}

The author would like to express sincere gratitude to Prof. Dr. Yousif A. Alshumaimeri and Dr. Ream Alqarni for their 
guidance, efforts, advice, assistance, and unremitting support in helping to complete this study.

\section{REFERENCES}

Ageel, M. (2011). The ICT proficiencies of university teachers in Saudi Arabia: A case study to identify challenges and encouragements. University of Southampton's Doctoral Research Journal. Hummingbird, 2, 55-60. Retrieved from http://eprints.soton.ac.uk/337733/1/ICT.pdf.

Akcaoğlu, M. (2008). Exploring technology integration approaches and practices of pre-service and in-service English language teachers.

Alharbi, A. M. (2013). Teachers'attitudes towards integrating technology: Case studies in Saudi Arabia and the United States. Master's Thesis. Paper 58. Grand Valley State University, Michigan. Retrieved from http://scholarworks.gvsu.edu/cgi/viewcontent.cgi? article $=1057 \&$ context=theses

Al-Maliki, S. Q. A. K. (2013). Information and communication technology (ICT) investment in the kingdom of Saudi Arabia: Assessing strengths and weaknesses. Journal of Organizational Knowledge Management, 2013, 1-15.

Almalki, G. \& Williams, N. (2012). A strategy to improve the usage of ICT in the Kingdom of Saudi Arabia primary school. International Journal of Advanced Computer Science and Applications, 3(10), 42-49. Retrieved from http://thesai.org/Downloads/Volume3No10/Paper_7-A Strategy_to_Improve_The_Usage_of_ICT_in_The Kingdom_of_Saudi_Arabia_Primary_School.pdf

Al-Mekhlafi, A. (2004). The internet and EFL teaching: The reactions of UAE secondary school English language teachers. Journal of Language and Learning, 2 (2), 88113. Retrieved from http://webspace.buckingham.ac.uk/ kbernhardt/journal/jllearn/2_2a/mekhlafi.pdf

Alshumaimeri, Yousif A. N. (2019). English language teaching in Saudi Arabia: An introduction. Riyadh, King Saud University Press.

Alshumaim, Y. \& Alhassan, R. (2010). Current availability and use of ICT among secondary EFL teachers in Saudi Arabia: Possibilities and reality. Paper presented at the Global Learn Asia Pacific 2010 Conference on Learning and Technology, Penang, Malaysia. Retrieved from http:// faculty.ksu.edu.sa/Alhassan/DocLib4/Current\%20Availability $\% 20$ and $\% 20$ Use $\% 20$ of $\% 20 I C T \% 20$ Among $\% 20$ Secondary\%20EFL\%20Teachers\%20in.pdf

Alshumaimeri, Y. \& Bamanger, E. (2013). The Effects of WebQuest Writing Instruction on the Writing Performance of Saudi Male EFL Learners. Procedia-Social and Behavioral Sciences, 83, 960-968.

Alshumaimeri, Y. A. (2008). Perceptions and attitudes toward using CALL in English classrooms among Saudi secondary teachers. The JALT CALL Journal, 4 (2), 29-46. Retrieved from http://journal.jaltcall.org/articles/4_2_Alshumaimeri.pdf

Alshumaimeri, Y., Gashan, A. \& Bamanger, E. (2019). Virtual worlds for collaborative learning: Arab EFL learners' attitudes. World Journal on Educational Technology: Current Issues. 11(3), 198-204.
Al-Sulaimani, A. A. (2010). The importance of teachers in integrating OCT into science teaching in intermediate schools in Saudi Arabia: A mixed-methods study. Doctoral Thesis. RMIT University, Melbourne.

Alwani, A. E. S. \& Soomro, S. (2010). Barriers to effective use of information technology in science education at Yanbu Kingdom of Saudi Arabia. In Safeeullah Soomro (Ed.), E-learning Experiences and Future (pp.3546). InTech. Retrieved from http://cdn.intechweb.org/ pdfs/10062.pdf

Aytekin, I., AbdulAziz, A. F., Barakat, H. H., \& Abdelrahman, A. S. M. (2012). Saudi secondary school teachers attitudes' towards using interactive whiteboard in classrooms. The Turkish Online Journal of Educational Technology, 11 (3), 286-296. Retrieved from http://www.tojet.net/articles/v11i3/11327.pdf

Bamanger, E. \& Alhassan, R. (2015). Exploring Podcasting in English as a Foreign Language Learners' Writing Performance. Journal of Education and Practice, 6(11), 63- 74 .

Bingimlas, K.A. (2009). Barriers to the successful integration of ICT in teaching and learning environments: A review of the literature. Eurasia Journal of Mathematics, Science \& Technology Education, 5 (3), 235-245.

Boulter, C. (2007). EFL and ESL teacher values and integrated use of technology in universities in the Asia-Pacific region. Retrieved from http://eprints.qut.edu. au/16525/1/Carmen_Boulter_Thesis.pdf

Cohen, C., Manion, L, \& Morrison, K. (2010). Research methods in education. London, England: Routledge.

Darus, S. \& Luin, H. W. (2008). Investigating teachers' use of computers in teaching English: A case study. The Journal of Teaching English With Technology, 8 (1). 1-18.

Dashtestani, R. (2012). Barriers to CA: Implementation: Iranian FL teachers' perspectives. JaltCallJournal, 8 (2), 55-70. Retrieved from http://journal.jaltcall.org/articles/8_2_Dashtestani.pdf

Earle, R. S. (2002). The integration of instructional technology into public education: Promises and challenges. ET Magazine, 42 (1), 5-13.

Egbert, J., Paulus, T. M., \& Nakamichi, Y. (2002). The impact of CALL instruction on classroom computer use: A foundation for rethinking technology in teacher education. Language Learning \& Technology, 6 (3), 108-126.

Fleming, J. (2013, October 7). Teaching in the internet, Retrieved from http://www.educationspace360.com/index. php/teaching-in-the-internet-or-digital-age-19727/

Gashan, A. \& Alshumaimeri, Y. (2015). Saudi Female Teachers' Attitudes toward Using Interactive Whiteboards in English as a Foreign Language Classrooms. Journal of International Education Studies, 8(12), 176-184.

Groff, J. \& Mouza, C. (2008). A framework for addressing challenges to classroom technology use. AACE Journal, 16 (1), 21-46. Retrieved from http://www.academia. edu/707629/A_Framework_for_Addressing_Challenges_to_Classroom_Technology_Use

Hakami, Y. A. A., Hussin, A. R. C., \& Dahlan, H. M. (2013). Critical success factors necessary for curriculum inte- 
gration of computer-based testing into Saudi secondary schools. Journal of Information Systems Research and Innovation, 22-30. Retrieved from http://seminar.spaceutm.edu.my/jisri/download/G_FinalPublished/Pub3 CSF_ComputerBasedTest.pdf

Hamed, E. E. D. \& Devi, K. K. S. (2011). Investigating Libyan teachers' attitudes towards integrating technology in teaching English in Sebha secondary schools. Academic Research International, 1 (3), 181.

Ismail, S. A. A., Almekhlafi, A. G., \& Al-Mekhlafy, M. H. (2010). Teachers' perceptions of the use of technology in teaching languages in United Arab Emirates' schools. International Journal for Research in Education, 27, 37-56.

Jacobsen, D. M. (1998). Adoption patterns of faculty who integrate computer technology for teaching and learning in higher education. Proceedings of the ED-MEDIA AND ED-TELECOM 98: World Conference on Educational Multimedia and Hypermedia \& World Conference on Educational Telecommunications, Freiburg, Germany, June 20-25. Retrieved from http://people.ucalgary. $\mathrm{ca} / \sim$ dmjacobs/phd/phd-results.html

Jones, A. (2004). A review of the research literature on barriers to the uptake of ICT by teachers. BECTA ICT Research. Retrieved from http://dera.ioe.ac.uk/1603/1/becta_2004_barrierstouptake_litrev.pdf

Kabilan, M. K. \& Rajab, B. M. (2010). The utilization of the Internet by Palestinian English language teachers focusing on uses, practices, and barriers and overall contribution to professional development. International Journal of Education and Development using Information and Communication Technology, 6 (3), 56-72. Retrieved from http://ijedict.dec.uwi.edu/include/getdoc. php? $\mathrm{id}=4234 \&$ article $=991 \&$ mode $=$ pdf

Khan, M. S. H., Hasan, M., \& Clement, C. K. (2012). Barriers to the introduction of ICT into education in developing countries: The Example of Bangladesh. International Journal of Instruction, 5 (2), 61-80. Retrieved from http://files.eric.ed.gov/fulltext/ED533790.pdf

Lee, K. (2000). English teachers' barriers to the use of computer-assisted language learning. The Internet TESL Journal, VI (12). Retrieved from http://iteslj.org/Articles/Lee-CALLbarriers.html

Lu, S. (2006). Barriers on ESL CALL programs in South Texas. MERLOT Journal of Online Learning and Teaching 2 (3), 158. Retrieved from http://jolt.merlot.org/vol2no3/lu.pdf

Marwan, A. (2008). Teachers' perceptions of teaching with computer technology: Reasons for use and barriers in usage. International Journal of Instructional Technology \& Distance learning, 5 (6).

Muir-Herzig, R. G. (2004). Technology and its impact in the classroom. Computers \& Education, 42, 111-131. Retrieved from http://te886.pbworks.com/f/Tech\%2Bin\%2Bthe $\% 2$ BClassroom.pdf

Mumtaz, S. (2000). Factors affecting teachers' use of information and communications technology: A review of the literature. Journal of Information Technology for Teacher Education, 9 (3), 319-342. Retrieved from http:// faculty.ksu.edu.sa/saad/Documents/factors $\% 20$ affecting $\% 20$ CALL $\% 20$ use.pdf

Nor, F. B. M. \& Vasu, S. M. (2010). Teachers' perceptions of lessons using computer-assisted language learning.

Okojie, M. C. P. O., Olinzock, A. A., \& Okojie-Boulder, T. C. (2006). The pedagogy of technology integration. Journal of Technology Studies, 32 (2), 66-71.

Olowa, O. W. (2012). An assessment of internet uses, practices, and barriers for professional development by agricultural science teachers in Lagos state. Education Research International, 1-7. Retrieved from http://www. hindawi.com/journals/edri/2012/503264/

Oyaid, A. (2009). Education Policy in Saudi Arabia and its Relation to Secondary School Teachers' ICT Use Perceptions and Views of the Future of ICT in Education. Ph.D. thesis, The University of Exeter, United Kingdom. Park, C. N. \& Son, J. (2009). Implementing computer-assisted language learning in the EFL classroom: Teachers' perceptions and perspectives. International Journal of Pedagogies and Learning, 5 (2), http://eprints.usq.edu. au/6887/1/Park_Son_IJPLv5n2_AV.pdf

Salehi, H. \& Salehi, Z. (2012). Integration of ICT in language teaching: Challenges and barriers. 2012 3rd International Conference on e-Education, e-Business, e-Management and e-Learning. International Proceedings of Economics Development and Research, 27, 215219. Retrieved from http://www.ipedr.com/vol27/40IC4E\%202012-F10037.pdf

Semary, H.E. (2011). Barriers to the effective use of technology in education: Case study of UAE university. Asian Transactions on Science \& Technology, 1 (5), 22-32.

Solanki, S. D. (2012). Use of technology in English language teaching and learning: An analysis. International Conference on Language, Medias, and Culture. Retrieved from http://www.ipedr.com/ vol33/030-ICLMC2012-L10042.pdf 